\title{
Comparison of Fall Risk Assessment Tools for Older Indonesian Adults in the Elderly Home and the Community
}

\author{
Perbandingan Kaidah Penilaian Risiko Jatuh pada Lansia di Rumah dan Panti
}

\author{
Indri Hapsari Susilowati', Susiana Nugraha', Sabarinah ${ }^{3}$, Bonardo Prayogo Hasiholan', \\ Supa Pengpid ${ }^{4,5}$, Karl Peltzer6,7 \\ ${ }^{1}$ Department of Occupational Health and Safety, Faculty of Public Health, Universitas Indonesia Depok \\ Building C, $1^{\text {st }}$ Floor Faculty of Public Health Universitas Indonesia, Depok, West Java 16424, Indonesia \\ ${ }^{2}$ Center for Family and Ageing Studies, University of Respati Indonesia \\ Jalan Bambu Apus I No.3, Cipayung, East Jakarta, 13890, Indonesia \\ ${ }^{3}$ Department of Biostatistics and Population Studies, Faculty of Public Health Universitas Indonesia, Depok \\ Building A $2^{\text {nd }}$ Floor Faculty of Public Health Universitas Indonesia, West Java 16424, Indonesia \\ ${ }^{4}$ ASEAN Institute for Health Development, Mahidol University \\ Salaya, Phutthamonthon District, Nakhon Pathom 73170, Thailand \\ ${ }^{5}$ Department of Research \& Innovation, University of Limpopo \\ 4th Floor, L Block Building, Turfloop, South Africa \\ ${ }^{6}$ Department for Management of Science and Technology Development, Ton Duc Thang University, Ho Chi \\ Minh City, 19 Nguyen Huu Tho street, Tan Phong ward, District 7, Vietnam \\ ${ }^{7}$ Faculty of Pharmacy, Ton Duc Thang University, Ho Chi Minh City \\ Room C011, 19 Nguyen Huu Tho street, Tan Phong ward, District 7, Vietnam
}

\begin{abstract}
Introduction: One of the causes of disability among elderly is falling. The ability to predict the risk of falls among this group is important so that the appropriate treatment can be provided to reduce the risk. The objective of this study was to compare the Stopping Elderly Accidents, Deaths, \& Injuries (STEADI) Initiative from the Centers for Disease Control and Prevention (CDC) and The Johns Hopkins Fall Risk Assessment Tool (JHFRAT) from the Johns Hopkins University. Methods: This study used the STEADI tool, JHFRAT, Activities-Specific Balance Confidence Scale (ABC), and The Geriatric Depression Scale (GDS). The study areas were in community and elderly home in both public and private sectors and the samples were 427 after cleaning. Results: The results for the STEADI and JHFRAT tools were similar where the respondents at highest risk of falling among women (STEADI: 49\%; JHFRAT: 3.4\%), in Bandung area (63.5\%; 5.4\%), in private homes $(63.3 \% ; 4.4 \%)$, non-schools $(54.6 \% ; 6.2 \%)$, aged 80 or older $(64.8 \% ; 6.7 \%)$ and not working $(48.9 \% ; 3.3 \%)$. The regression analysis indicated that there was a significant relationship between the risk factors for falls in the elderly determined by the JHFRAT and STEADI tools: namely, region, type of home, age, disease history, total GDS and ABC averages. Conclusion: Despite the similarity in the risk factors obtained through these assessments, there was a significant difference between the results for the STEADI tool and the JHFRAT. The test strength was $43 \%$. However, STEADI is more sensitive to detect fall risk smong elderly than JHFRAT.
\end{abstract}

Keywords: Activities-Specific Balance Confidence scale, elderly, fall risk, The Johns Hopkins Fall Risk Assessment Tool, the Stopping Elderly Accidents, Deaths, \& Injuries

\section{ABSTRAK}

Pendahuluan: Laboratorium Klinik merupakan tempat kerja yang perlu dirancang sesuai dengan standar kesehatan dan keselamatan kerja untuk menciptakan lingkungan kerja yang aman. Kecelakaan kerja yang fatal dapat berakibat pada timbulnya luka yang diakibatkan karena penggunaan peralatan yang tidak tepat, keracunan akibat bahan kimia yang berada di laboratorium klinik dan penularan penyakit berbahaya. Metode: Penelitian ini bersifat observasional dengan pendekatan cross sectional. Populasi dalam penelitian ini adalah karyawan yang berjumlah 15 orang yang merupakan analis kesehatan di Laboratorium Klinik X Regional Jawa Timur. Teknik penentuan jumlah sampel menggunakan total sampling. Penelitian ini dilakukan pada Juli-September 2018. Variabel dependen penelitian adalah penggunaan APD,

(C2019 IJOSH All right reserved. Open access under CC BY NC-SA license doi: 10.20473/ijosh.v8i3.2019.241-248 Received September 02, 2019, received in revised form October 30, 2019, Accepted December 20, 2019, Published: December 2019 
dan variabel independen adalah lack of control, dan basic causes. Data dalam penelitian ini dianalisis menggunakan uji korelasi chi square dan spearman. Hasil: Sebesar 53,3\% karyawan di Laboratorium Klinik X Regional Jawa Timur menggunakan APD dengan sesuai. Terdapat hubungan yang kuat antara pengetahuan dengan penggunaan APD ( $r=0,607)$. Terdapat hubungan yang kuat antara motivasi dengan penggunaan APD $(r=0,600)$. Terdapat hubungan yang kuat antara ketersediaan APD dengan penggunaan APD ( $r=0,756)$. Simpulan: Terdapat hubungan yang kuat antara pengetahuan, motivasi dan ketersediaan APD dengan penggunaan APD.

Kata kunci: Activities-Specific Balance Confidence scale, The Johns Hopkins Fall Risk Assessment Tool, lansia, risiko jatuh, the Stopping Elderly Accidents, Deaths, Injuries

\author{
Author for Correspondence: \\ Indri Hapsari Susilowati \\ Email: indri@ui.ac.id \\ Telephone: +6281255564412
}

\section{INTRODUCTION}

An indicator of public health success is the increase in life expectancy. The life expectancy in Indonesia reached 64.5 years in 2000 and 69.43 years in 2010. In 2011, it increased to 69.65 years. By 2017, it was 72.59 years for women (Statistics Indonesia, 2017b). The increased in the life expectancy which has an impact on increasing the number of the elderly population as the consequences.

In Indonesia, the elderly accounted for $7.18 \%$ of the population in $2000,7.56 \%$ in 2010 and $7.59 \%$ in 2011 (Statistics Indonesia, 2017a). The results from the 2013 edition of Riskesdas showed that this increase in the average age was accompanied by a higher incidence of disability and disease complications (Health Research and Development Agency, 2013). In addition, the global trend regarding the increased occurrence of noncommunicable and degenerative diseases is mirrored in Indonesia. For example, there was an increase in the prevalence of stroke from 8.3 per 1,000 people in 2007 to 12.1 per 1,000 in 2013 (Health Research and Development Agency, 2013). The 2007 edition of kartika data indicate that $10 \%$ of the elderly aged 65 and $25 \%$ of those aged 75 had a major disability (Health Research and Development Agency, 2007). According to the population projection data, in 2017, there would have been 23.66 million elderly people in Indonesia: $9.03 \%$ of the population. It is predicted that the elderly population would be 27.08 million in 2020, 33.69 million in 2025, 40.95 million in 2030 and 48.19 million in 2035 (Statistics Indonesia, 2017b).

One of the causes of disability in the elderly is falling. Injuries related to falls have been identified as a major public health problem (World Health
Organization, 2007). Falls can result in a decline in quality of life. For example, partial or total care may be needed. In a study conducted in the elderly community in six middle-income countries, the average prevalence of injuries related to falls was $4.0 \%$. This included $6.6 \%$ in India, $3.1 \%$ in China and $1.0 \%$ in South Africa (Joe, Rudra and Subramanian, 2015). According to Health Research and Development Agency (2013), the prevalence of comorbidities resulting from injuries from falls was $40.9 \%$ in the Indonesian elderly. For individuals aged $65-74$, the prevalence of falls was $67.1 \%$, and for those older than 75, it was 78.2\% (Health Research and Development Agency, 2013).

The Fall Risk Instruments that widely use, are include Stopping Elderly Accidents, Deaths, \& Injuries (STEADI) Initiative from the Centers for Disease Control and Prevention (CDC) and The Johns Hopkins Fall Risk Assessment Tool (JHFRAT) from the Johns Hopkins University (Poe et al., 2007; Hnizdo et al., 2013; Kaminska, Brodowski and Karakiewicz, 2015; Lohman et al., 2017; Hojati, Dadgari and Mirrezaie, 2018). Besides that, fall risk instruments in some countries are develop by modified those tools, such as Thai-FRAT modified by JHFRAT (Thiamwong et al., 2008). However, a few researchers used it to predict fall risk for the Indonesia elderly. The ability to predict the risk of falls in the elderly is important so that the appropriate treatment can be provided to reduce the risk. Fall risk assessment tools have been used in elderly populations. However, such tools are not yet available for the Indonesian elderly. Therefore, the objective of this study was to compare those fall risk instruments for the Indonesian elderly and which can be considered to develop the Indonesian fall risk assessment tools.

\section{METHODS}

The sample size calculation for the regression analysis was based on Van Voorhis and Morgan (2007). The overall model is $50+8 \mathrm{k}$, where $\mathrm{k}$ is 
a number of independent variables. This study contained 9 independent varibales, such as sex, region, type of home, education, age, history of disease, working status, self confidence not to fall scale, and depression symptom. Therefore, the minimum for overall model sample size was $50+8$ $\times 9=122$. However for each independent variable should consist sample at least $104+\mathrm{k}$. In this study, it was $104+9=113$. Because the number of overall model was higher than individual model so this study consider the highest number of sample; 122. This study used 3 groups, there were the community, private elderly home, and public elderly home then the minimum sample size was $122 \times 3=366$. Additional cases were collected to prevent outliers, it added $20 \%$ but after data cleaning, the sample size was 427. While, the instrument of Activities-Specific Balance Confidence Scale (ABC) to see the level of confidence not to fall, and Geriatric Depression Scale (GDS) to see the depressive symptoms. Variable dependent was Risk of fall, used JHFRAT and STEADI.

The questionnaire, which was originally in English, was translated by two independent bilingual translators into Bahasa. Another bilingual translator who was not familiar with the original instrument back-translated the reconciled target language version. Written informed consent was obtained from the participants before their start of the study. The study was approved by the Ethical Committee of Faculty of Public Health, Universitas Indonesia, Indonesia. The approval number was 125/UN2.F10/ PPM.00.02/2018.

The inclusion criteria were elderly people aged 60 and older. They had to be independent and able to communicate well. Elderly people with a history of disease, such as cardiovascular dysfunction, stroke, anaemia or dementia, were included in the group of participants at high risk for falls. The exclusion criteria were elderly individuals who were bedridden, required total care or were experiencing mental disorders. The analyses were performed with IBM SPSS Statistics for Windows, Version 24.0 software.

\section{RESULTS}

The results for the STEADI tool indicated that the respondents at highest risk for falling were women (49\%), individuals living in Bandung area $(63.5 \%)$, in private homes $(63.3 \%)$, non-schools $(54.6 \%)$, aged 80 or older $(64.8 \%)$ and not working $(48.9 \%)$ as shown in Table 1.
According to the results of the JHFRAT in Table 1, the respondents at the greatest risk for falls were women (3.4\%), individuals living in Bandung area $(5.4 \%)$, in private homes $(4.4 \%)$, non-schools $(6.2 \%)$, aged 80 or older $(6.7 \%)$ and not working $(3.3 \%)$ as shown in Table 1 . After going through the analysis process, there were significant differences in JHFRAT and STEADI for strength testing by $43 \%$ (table 2).

The results of the regression analysis indicated that there was a significant relationship (p-value $=0.0001$ ) between the risk factors for falls in the elderly determined by the JHFRAT and the STEADI tool, namely; region, type of home, age, disease history, total GDS and ABC average. The risk for falls was higher in the elderly in Bandung among those who were living in the community. It was also higher for those who were older, had more disease history, had depressive symptoms and low balance confidence as shown in Table 3 and Table 4.

However, the strength of the test was only $34.5 \%$ for the JHFRAT and $44.2 \%$ for the STEADI tool. Therefore, the regression line equation that was obtained could explain only $34.5-44.2 \%$ of the fall risk variation. It was also likely that the line equation was not strong enough to explain the risk variable of falling.

\section{DISCUSSION}

In 2007, Poe explained that the JHFRAT was developed on the basis of evidence from adult patients and acute care hospitals. It is the most widely used assessment around the world; however, further studies on the reliability and validity of this scale were still needed (Poe et al., 2007). This might be one of the reasons that the JHFRAT has had to be modified. Some researchers have adapted it to suit the characteristics of specific populations. For example, the elderly in the United States will be very different from the elderly in Asia (Hojati, Dadgari and Mirrezaie, 2018). The same would be true for the external factors, such as the environment, that would affect the incidence of falls. A study conducted in Iran indicated that the JHFRAT was valid and reliable for the Iranian elderly. The incidence of falls in the subjects was reported as approximately $50 \%$. Cronbach's alpha for the tool items was calculated separately. The items had appropriate and positive correlation. Cronbach's alpha for the Persian version of the tool was 0.73 (Hojati, Dadgari and Mirrezaie, 2018). In 2012, a prospective cohort study of elderly patients receiving home health care 
visits was conducted to evaluate the validity and reliability of the modified JHFRAT (mJHFRAT). The study confirmed that the mJHFRAT is a simple and easy-to-use multifactor fall risk assessment tool with promising sensitivity, specificity and inter-rater reliability for identifying patients at risk of falls with injuries in community-dwelling elderly populations (Hnizdo et al., 2013).

The STEADI application is an effort to reduce the risk of falls in the elderly (Center of Diseas Control, 2019). Some studies have shown that it is a form of intervention for falling events. A metaanalysis of multifactorial fall risk interventions found that The STEADI significantly reduced the rate of falls (rate ratio $=0.76 ; 95 \%$ CI: $0.67,0.86$ ) but not the risk of falling (risk ratio $=0.93 ; 95 \% \mathrm{CI}$ : 0.86, 1.02) (Gillespie et al., 2009). In 2017, a survey using cohort data found that the adapted STEADI tool was a valid measure for predicting fall risk. Further efforts to standardize the screening for fall risk and to coordinate clinical and community-based fall prevention initiatives are warrant (Lohman et al., 2017). Johnston et al. (2019) recently demonstrated that the implementation of STEADI fall risk screening and prevention strategies among older adults in primary care settings could reduce fallrelated hospitalizations and lower the associated health care costs (Johnston et al., 2019) . In another study, older adults at risk for fall with a Fall Plan of Care (FPOC) was 0.6 times less likely to have a fall-related hospitalization than those without an FPOC $(p=0.041)$. Their post-intervention outcomes were similar to those who were not at risk (Johnston et al., 2019). In Indonesia, many studies have been conducted with the elderly; however, the use of the

Table 1. Results of Fall Risk Categorized by STEADI dan JHFRAT

\begin{tabular}{|c|c|c|c|c|c|c|c|c|}
\hline \multirow{3}{*}{ Risk Factors } & \multicolumn{4}{|c|}{ STEADI } & \multicolumn{4}{|c|}{ JHFRAT } \\
\hline & \multicolumn{2}{|c|}{ Low Risk } & \multicolumn{2}{|c|}{ High Risk } & \multicolumn{2}{|c|}{ Low Risk } & \multicolumn{2}{|c|}{ High Risk } \\
\hline & $\mathbf{n}$ & $\%$ & $\mathbf{n}$ & $\%$ & $\mathbf{n}$ & $\%$ & $\mathbf{n}$ & $\%$ \\
\hline \multicolumn{9}{|l|}{ Sex } \\
\hline Male & 85 & 62 & 52 & 38 & 135 & 98.5 & 2 & 1.5 \\
\hline Female & 148 & 51 & 142 & 49 & 280 & 96.6 & 10 & 3.4 \\
\hline \multicolumn{9}{|l|}{ Region } \\
\hline Jakarta & 86 & 64.7 & 47 & 35.3 & 129 & 97 & 4 & 3 \\
\hline Bandung & 54 & 36.5 & 94 & 63.5 & 140 & 94.6 & 8 & 5.4 \\
\hline Yogyakarta & 93 & 63.7 & 53 & 36.3 & 146 & 100 & 0 & 0 \\
\hline \multicolumn{9}{|l|}{ Types of home } \\
\hline Public & 73 & 58.9 & 51 & 41.1 & 123 & 99.2 & 1 & 0.8 \\
\hline Private & 33 & 36.7 & 57 & 63.3 & 86 & 95.6 & 4 & 4.4 \\
\hline Community & 127 & 59.6 & 86 & 40.4 & 206 & 96.7 & 7 & 3.3 \\
\hline \multicolumn{9}{|l|}{ Education } \\
\hline Never & 59 & 45.4 & 71 & 54.6 & 122 & 93.8 & 8 & 6.2 \\
\hline Not graduated & 44 & 55.7 & 35 & 44.3 & 77 & 97.5 & 2 & 2.5 \\
\hline Elementary School & 56 & 58.9 & 39 & 41.1 & 94 & 98.9 & 1 & 1.1 \\
\hline $\begin{array}{l}\text { Junioir High } \\
\text { School }\end{array}$ & 24 & 55.8 & 19 & 44.2 & 43 & 100 & 0 & 0 \\
\hline Senior High School & 26 & 59.1 & 18 & 40.9 & 43 & 97.7 & 1 & 2.3 \\
\hline University & 23 & 71.9 & 9 & 28.1 & 32 & 100 & 0 & 0 \\
\hline \multicolumn{9}{|l|}{ Age } \\
\hline 60-69 years old & 122 & 65.9 & 63 & 34.1 & 184 & 99.5 & 1 & 0.5 \\
\hline $70-79$ years old & 74 & 54 & 63 & 46 & 133 & 97.1 & 4 & 2.9 \\
\hline$\geq 80$ years old & 37 & 35.2 & 68 & 64.8 & 98 & 93.3 & 7 & 6.7 \\
\hline \multicolumn{9}{|l|}{ Working } \\
\hline No & 168 & 51.1 & 161 & 48.9 & 318 & 96.7 & 11 & 3.3 \\
\hline Yes & 65 & 66.3 & 33 & 33.7 & 97 & 99 & 1 & 1 \\
\hline
\end{tabular}


Table 2. The difference of fall risk result between STEADI dan JHFRAT

\begin{tabular}{ccccccc}
\hline \multirow{2}{*}{ Risk } & \multicolumn{2}{c}{ STEADI } & \multicolumn{2}{c}{ JHFRAT } & \multirow{2}{*}{ p-value } & \multirow{2}{*}{ R2 } \\
\cline { 2 - 5 } & $\mathbf{n}$ & $\mathbf{\%}$ & $\mathbf{n}$ & $\mathbf{\%}$ & & \\
\hline Low & 233 & 54.6 & 415 & 97.2 & & \\
High & 194 & 45.4 & 12 & 2.8 & 0.0001 & 0.431 \\
\hline Total & 427 & 100 & 427 & 100 & & \\
\hline
\end{tabular}

Table 3. The Fall Risk Factor affecting the result of JHFRAT

\begin{tabular}{cccc}
\hline Risk Factors & r & R2 & p-value \\
\hline Region & 0.588 & 0.345 & 0.0001 \\
Type of elder & & & \\
care facility & & & \\
Age History & & & \\
of disease & & & \\
GDS & & & \\
ABC & & & \\
\hline
\end{tabular}

The linear regression equation for JHFRAT is:

$$
\begin{aligned}
& \text { JHFRAT }=18.696+0.352 * \text { region }+0.245 * \text { Type } \\
& \text { elder care }+0.103 * \text { age }+0.433 * \text { history of } \\
& \text { disease }+0.127 * \mathrm{GDS}-0.012 * \mathrm{ABC}
\end{aligned}
$$

JHFRAT and the STEADI tools in studies related to the incidence of falls in the elderly were very low.

The present study found that of the three cities in Indonesia, Bandung was the city with the highest risk level. Several factors contributed to this high risk, particularly the land contour in Bandung City was wavy and tend to slope. Based on the observation, it was different with Jakarta city and Yogyakarta City where mostly flat. A review by Sabatini (2015) identified some of the contributory external factors in fall risk (Sabatini, Tambunan and Kusuma, 2015) . They include slipping, tripping and falling because of loss of balance due to environmental factor. Sight-related elements and safety equipment have also been found to be the factors (Sabatini, Tambunan and Kusuma, 2015). This was confirmed by Rudy and Setyanto (2019), who found a significant relationship between limb system disorders $(\mathrm{p}=0.038)$, visual impairment $(\mathrm{p}$ $=0.019)$ and home environment $(p=0.007)$ and fall risk in the elderly (Rudy and Setyanto, 2019).

The Bandung participants included the dependent elderly (elderly who need help in doing basic activities). This is supported by the results in this study study, which indicated the independence
Table 4. The Fall Risk Factor Affecting the Result of STEADI

\begin{tabular}{cccc}
\hline Risk Factors & r & R2 & p-value \\
\hline Region & 0.665 & 0.442 & 0.0001 \\
Type of elder & & & \\
care facility & & & \\
Age History of & & & \\
disease & & & \\
GDS & & & \\
\hline
\end{tabular}

Regression linear equation for STEADI is:
STEADI $=16.095+0.626 *$ region $+0.266 *$ Type of elder care facility $+0.03 *$ age $+0.276^{*}$ history of disease $+0.282 * \mathrm{GDS}-0.042 * \mathrm{ABC}$

level of the elderly (60-69 years old) in performing daily living activities: 15 participants $(72 \%)$ had partial dependence, $3(14 \%)$ were independent and 3 (14\%) were totally dependent. Most of the elderly at the Tresna Wredha Senjarawi Social Institution had partial dependence for their life activities. Health programs are expected to be developed to increase the independence of the elderly (Rohaedi, Putri and Karimah, 2016). There were several risk factors for falls; however, Bandung has the highest number of elder healthcare facilities in Indonesia (Data and Information Center, 2017). Although the elderly in Bandung had the highest risk factors, Yogyakarta had the largest elderly population. This is supported by the availability of special elder healthcare facilities, including the top three in Indonesia (Data and Information Center, 2017). Yogyakarta is an appropriate pilot city to implement several programs, such as gymnastics to improve the health of the elderly. Some studies by Suhartati, (2014); Supriyono (2015) indicated that the majority of the elderly in a gymnastics group had a moderate fall rate of $40 \%$ and those non-gymnastic group had $30 \%$ of high risk to fall. The results of statistical analysis showed significant different in the fall risk between the elderly who participated in gymnastics at PSTW Kasongan Yogyakarta with the elderly group who did not.

The results of the present study indicated that the fall risk was higher for older people who lived in communities. The availability of a safe environment, including a home adapted for the physical condition of the elderly, can reduce the risk. A study found that the environment had a major effect on the incidence of falls in the elderly (Fristantia, Zulfitri and Hasneli, 2018). Health programs, such as gymnastics, provided by institutions have a large 
role in helping the elderly to maintain good physical condition and balance to avoid falling (Kartika, Nurmasitoh and Pramaningtyas, 2017). Caregiver supervision or nursing assistance can also contribute to the decrease in the number of falls. This was similar to Utami and Suratini (2017) findings where the existence of optimal family support (people around) was strongly associated with the incidence of falling in the elderly. Different conditions with the elderly in the community who have a lot of physical activities and not a priority concern for the surrounding environment than in elderly home.

In Indonesia, elder services are provided by the government and the private sector. Eldercare facilities and shelter services, such as nursing or elderly homes, are managed by social departments. The residents are usually the elderly who are homeless or have no family which managed by the government do not require any fee. In contrast, the nursing homes that are managed by the private sector have better facilities because they use a business model. The residents are required to pay; thus, such facilities generally attract the elderly who can afford them. There are almost no homeless elderly in this institution and some voluntarily become part of the institution or not forced by children or families.

Falls occur in $30-60 \%$ of older adults each year, and $10-20 \%$ of these resulted in injury, hospitalization and/or death. Most falls were associated with identifiable risk factors, include weakness, unsteady gait, confusion and psychoactive medications (Rubenstein, 2006). Falls and their associated injuries are common. They usually resulted from the interactions of multiple fall risk factors, many of which may be modifiable (Phelan et al., 2015). Risk factors can be identified through clinical examinations. They include home hazards, medications and treatment for cognitive and visual impairments, functional limitations orthostatic hypotension and gait and balance abnormalities (Kwan and Straus, 2014).

The result revealed that the fall risk was significantly related with age. The average age of the elderly is increasing, and so is the risk for falling. This was due to their physiological and psychological ability were decreasing. This was evidenced by Deniro, which found a relationship between age and fall risk among patients in hospital $(\mathrm{r}=0.334, \mathrm{p}<0.05)$ (Deniro, Sulistiawati and Widajanti, 2017). This confirmed the findings of previous study, where it showed among 265 elderly patients, $23.4 \%$ had impairments in the ability to perform daily activities; $70 \%$ were $60-69$ years old (Deniro, Sulistiawati and Widajanti, 2017). Those aged $>80$ years had a reduced ability to perform significant daily activities (Gupta, Yadav and Malhotra, 2017). These results were similar to a study in Japan which the incidence of falls increased with age (Yokoya, Demura and Sato, 2007). A study of the elderly who lived at home found that the risk factors for falls were due to the heart problems $(\mathrm{p}=$ 0.006), limb disorders $(p=0.002)$, nervous disorders $(\mathrm{p}=0.024)$, visual impairment $(\mathrm{p}=0.004)$, hearing loss $(p=0.007)$, walking aids $(p=0.000)$ and the environment $(\mathrm{p}=0.003)$ (Fristantia, Zulfitri and Hasneli, 2018)

Besides that, health history also can be a contributing factor. This study also found significant of history of disease with falling. The medicines taken and a decrease in the individual's physiological condition can contribute to falls. The prevalence of falling increases with the incidence of chronic disease such as circulatory disease, chronic obstructive pulmonary disease, depression and arthritis (Lawlor, Patel and Ebrahim, 2003). For example, elderly individuals often suffer from diabetes mellitus, which is a major risk factor of falling due to their poor balance. Sixty-four participants (42 diabetes and 22 controls) reported experienced at least one injurious fall or two noninjurious falls ('fallers'). The risk factors were identified through univariate logistic regression (odds ratio $=2.25 ; 95 \%$ CI 1.21-4.15, $\mathrm{p}=0.010(\mathrm{De}$ Mettelinge et al., 2013).

The GDC results provided data on depression levels in the elderly. The higher the depression level, the greater was the risk of falling. Depression is associated with postural abnormalities in the standing position, and this may create a unbalance and predisposition to falling. In clinical practice, more attention should be given to the diagnosis and treatment of depression in old fallers (Turcu et al., 2004). Therefore, fall prevention strategies should include the evaluation and treatment of depression and cognitive disturbances among elderly (Kaminska, Brodowski and Karakiewicz, 2015).

According to the results for the $\mathrm{ABC}$, low self-confidence created a high risk of falling. In addition, feelings of anxiety, panic, and unbelieve could dependent activity without fall which are prevalent in the elderly, were also the contributing factors. Harkitasari (2018) conducted a study among 53 elderly: 50\% men and 26 (50\%) women aged $61-90$. The mean age was $71.6 \pm 6.5 ; 17.3 \%$ of the 
participants had a history of falls. The total mean for the results of the $\mathrm{ABC}$ scale indicated a significant difference between women and men $(81.2 \pm 14.1$ vs. $90 \pm 12.8 ; p<0.05)$ and the fallers and nonfallers $(73.5 \pm 13.6$ vs. $88.2 \pm 12.9 ; \mathrm{p}=0.01)$. The $\mathrm{ABC}$ scale with a cut-off of $82.9 \%$ has significant association with falls $(\mathrm{p}=0.01$; prevalence ratio $=$ 7.0; 95\% CI 1.6-49.8. Harkitasari (2018) concluded that the total $\mathrm{ABC}$ scale was significantly predictive for falls in the elderly. Other studies also obtained the similar results. The ABC-H scores were found to be significantly and independently related with future falls in the community-dwelling among older Indian adults. The ability of the ABC-H scale to predict future falls were adequate with high sensitivity and specificity values (Moiz et al., 2017).

\section{CONCLUSION}

The same results were obtained for the JHFRAT and STEADI tools, where the respondents at highest risk for falling were women. Other risk factors were among the elderly residence in Bandung, live in private home, not attending school, being 80 years or older and not working. Meanwhile, the results of the regression analysis showed a significant correlation between the same risk factors that were obtained with the JHFRAT and the STEADI tool. The factors were region, type of home, age, disease history, total GDS score and ABC average. Despite the similarity in the risk factors obtained through these assessments, there was a significant difference between the results for the STEADI tool and the JHFRAT. The test strength was $43 \%$.

\section{ACKNOWLEDGEMENT}

This work was supported by grants research partnership overseas 2018, funded by the Ministry of Research and Higher Education, Republic of Indonesia No. 120/SP2H/PTNBH/DRPM/2018.

\section{REFERENCES}

Center of Diseas Control (2019) STEADI Older Fall Prevention, United States of America: Department of Health \& Human Services.

Data and Information Center (2017) Analisis Situasi Lansia dii Indonesia. Jakarta: Ministry of Health of the Republik of Indonesia.

Deniro, A. J. N., Sulistiawati, N. N. and Widajanti, N. (2017) 'Hubungan antara Usia dan Aktivitas
Sehari-Hari dengan Risiko Jatuh Pasien Instalasi Rawat Jalan Geriatri', Jurnal Penyakit Dalam Indonesia, 4(4), pp. 199-203.

Fristantia, D. A., Zulfitri, R. and Hasneli, Y. (2018) 'Analisis Faktor-Faktor Yang Berhubungan Dengan Risiko Jatuh Pada Lansia Yang Tinggal Dirumah', Jurnal Online Mahasiswa Perpustakaan Fakultas Keperawatan, 5(1), pp. 161-170.

Gillespie, L. D. et al. (2009) Interventions for Preventing Falls in Older People Living in the Community. New Jersey: John Wiley \& Sons, Ltd.

Gupta, S., Yadav, R. and Malhotra, A. K. (2017) 'Assessment of physical disability using Barthel index among elderly of rural areas of district Jhansi (U.P), India', Journal of Family Medicine and Primary Care, 5(4), pp. 853-857.

Harkitasari, S. (2018) 'Relationship between Activities Specific Balance Confidence (ABC) Scale with Age and Falls on Elderly in Wanasraya Nursing Home Denpasar', in IOP Conference Series: Materials Science and Engineering, pp. $1-4$.

Health Research and Development Agency (2007) Riset Kesehatan Dasar 2007. Jakarta: Ministry of Health of the Republik of Indonesia.

Health Research and Development Agency (2013) Riset Kesehatan Dasar 2013. Jakarta: Ministry of Health of the Republik of Indonesia.

Hnizdo, S. et al. (2013) 'Validity and reliability of the modified John Hopkins Fall Risk Assessment Tool for elderly patients in home health care', Geriatric Nursing, 34(5), pp. 423-427.

Hojati, H., Dadgari, A. and Mirrezaie, S. M. (2018) 'Validity and Reliability of Persian Version of Johns Hopkins Fall Risk Assessment Tool among Aged People', Qom University of Medical Sciences, 12(2), pp. 45-53.

Joe, W., Rudra, S. and Subramanian, S. V. (2015) 'Horizontal inequity in elderly health care utilization: Evidence from India', Journal of Korean Medical Science, 30(Supplementary 2), pp. S155-S166.

Johnston, Y. A. et al. (2019) 'Implementation of the Stopping Elderly Accidents, Deaths, and Injuries Initiative in Primary Care: An Outcome Evaluation', The Gerontologist, 59(6), pp. $1182-1191$.

Kaminska, M. S., Brodowski, J. and Karakiewicz, B. (2015) 'Fall Risk Factors in Community-Dwelling Elderly Depending on Their Physical Function, Cognitive Status and Symptoms of Depression', 
International Journal of Environmental Research and Public Health, 12(4), pp. 3406-3416.

Kartika, A. D., Nurmasitoh, T. and Pramaningtyas, M. D. (2017) Perbedaan Hasil Tes Timed Up And Go Lansia yang Tinggal di Balai Pelayanan Sosial Tresna Werdha dibandingkan dengan Lansia yang Tinggal di Komunitas. A Scientific Paper. Yogyakarta: Faculty of Medicine, Universitas Islam Indonesia: Universitas Islam Indonesia.

Kwan, E. and Straus, S. E. (2014) 'Assessment and Management of Falls in Older People', Canadian Medical Association Journal, 186(16), pp. E610-E621.

Lawlor, D. A., Patel, R. and Ebrahim, S. (2003) 'Association between Falls in Elderly Women and Chronic Diseases and Drug Use: Cross Sectional Study', BMJ, 327(7417), pp. 712-717.

Lohman, M. C. et al. (2017) 'Operationalisation and Validation of the Stopping Elderly Accidents, Deaths, and Injuries (STEADI) Fall Risk Algorithm in a Nationally Representative Sample', Journal of Epidemiology and Community Health, 71(12), pp. 1191-1197.

De Mettelinge, T. R. et al. (2013) 'Understanding the Relationship between Type 2 Diabetes Mellitus and Falls in Older Adults: A Prospective Cohort Study', PLoS One, 8(6), pp. 1-5.

Moiz, J. A. et al. (2017) 'Activities-Specific Balance Confidence Scale for Predicting Future Falls in Indian Older Adults', Clinical Interventions in Aging, 12, pp. 645-651.

Phelan, E. A. et al. (2015) 'Assessment and Management of Fall Risk in Primary Care Settings', Medical Clinics of North America, 99(2), pp. 281-293.

Poe, S. S. et al. (2007) 'The Johns Hopkins Fall Risk Assessment Tool: Post Implementation Evaluation', Journal of Nursing Care Quality, 22(4), pp. 293-298.

Rohaedi, S., Putri, S. T. and Karimah, A. D. (2016) 'Tingkat Kemandirian Lansia dalam Activities Daily Living di Panti Sosial Tresna Werdha Senja Rawi', Jurnal Pendidikan Keperawatan Indonesia, 2(1), pp. 16-21.

Rubenstein, L. Z. (2006) 'Clinical Risk Assessment, Interventions and Services Falls in Older People: Epidemiology, Risk Factors and Strategies for Prevention', Age and Ageing, 35(Supplementary 2), pp. 37-41.

Rudy, A. and Setyanto, R. B. (2019) 'Analisis Faktor yang Mempengaruhi Risiko Jatuh pada
Lansia', Jurnal Ilmiah Ilmu Kesehatan: Wawasan Kesehatan, 5(2), pp. 162-166.

Sabatini, S. N., Tambunan, L. and Kusuma, H. E. (2015) 'Elderly House Environmental Fall Risk Factors in Yogyakarta', in The International Symposium on Architectural Interchanges in Asia, pp. 485-488.

Statistics Indonesia (2017a) Proyeksi Penduduk Indonesia 2010-2035. Jakarta: Statistics Indonesia.

Statistics Indonesia (2017b) Statistik Indonesia 2017 (Statistical Yearbook of Indonesia 2017). Jakarta: Statistics Indonesia.

Suhartati, C. (2014) Perbedaan Risiko Jatuh pada Lanjut Usia yang Mengikuti Senam dengan yang Tidak Mengikuti Senam di PSTW Yogyakarta Unit Budi Luhur. Undergraduate Thesis. Yogyakarta: Nursing Science Study Program, Sekolah Tinggi Ilmu Kesehatan 'Aisyiyah.

Supriyono, E. (2015) 'Aktifitas Fisik Keseimbangan Guna Mengurangi Resiko Jatuh Pada Lansia', Jorpres (Jurnal Olahraga Berprestasi), 11(2), pp. 91-101.

Thiamwong, L. et al. (2008) 'Thai Falls Risk Assessment Test (Thai-FRAT) Developed for Community-Dwelling Thai Elderly', Journal of the Medical Association of Thailand, 91(12), pp. $1823-1832$.

Turcu, A. et al. (2004) 'Falls and Depression in Older People', Gerontology, 50(5), pp. 303-308.

Utami, N. and Suratini, S. (2017) Hubungan Dukungan Keluarga dengan Risiko Jatuh pada Lansia di Desa Krasakan Lumbungrejo Tempel Sleman Yogyakarta. Undergraduate Thesis. Yogyakarta: Faculty ofHealth Sciences,Universitas 'Aisyiyah.

Van Voorhis, C. R. W. and Morgan, B. L. (2007) 'Understanding Power and Rules of Thumb for Determining Sample Sizes', Tutorials in Quantitative Methods for Psychology, 3(2), pp. 43-50.

World Health Organization (2007) WHO Global Report on Fall Prevention in Older Age. Geneva: World Health Organization.

Yokoya, T., Demura, S. and Sato, S. (2007) 'Relationships between Physical Activity, ADL Capability and Fall Risk in Community-Dwelling Japanese Elderly Population', Environmental Health and Preventive Medicine, 12(1), pp. 25-32. 